\title{
Quantifying the impact of urban runoff injection on groundwater enhancement in a semi-arid environment using SWMM and MOFLOW Model
}

\author{
Babaie S. ${ }^{1}$, Ghazavi R. ${ }^{1 *}$ and Erfanian M. ${ }^{2}$ \\ ${ }^{1}$ Department of Watershed Management, Faculty of Natural Resources, University of Kashan, Iran \\ 2Department of Watershed Management, Faculty of Natural Resources, Urmia University, Iran \\ Received: 12/01/2020, Accepted: 05/11/2021, Available online: 26/11/2021 \\ *to whom all correspondence should be addressed: e-mail: ghazavi@kashanu.ac.ir \\ https://doi.org/10.30955/gnj.003275
}

\section{Graphical abstract}

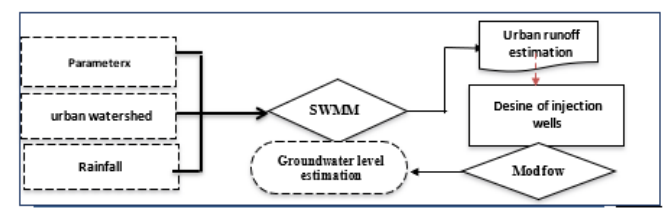

\section{Abstract}

In the urban area, surface runoff can be utilized effectively to improve groundwater table through rainwater harvesting. The main aims of this study were to:1) investigate the potential of the surface runoff to inject into Urmia aquifer and increase groundwater recharge of this aquifer using SWMM - MOFLOW Model, 2) to investigate the quality of the urban runoff for aquifer recharge, and 3) to investigate the feasibility and effeteness of the artificial recharge via injection wells in a semi-arid area. Urmia city with an area of $930 \mathrm{Km}^{2}$ is located at the West of the Urmia Lake in the North-West of Iran. The study aquifer has a negative groundwater budget, while some of the sub basin in the study watershed is prone to flood in the falling season. In this study, based on the location of surcharged channels, the quantity of rechargeable surface runoff to inject into the aquifer was estimated via SWMM model. Calibrated MODFLOW model was applied to predict the potential effects of the injectable water runoff on the groundwater surface. Estimated runoff by SWMM model was used as the input of the MODFLOW model. The quantity of the heavy metals $\left(\mathrm{Fe}^{2+}, \mathrm{Zn}^{2+}, \mathrm{Mn}^{2+}, \mathrm{Pb}\right.$ and $\left.\mathrm{Cu}^{2+}\right)$ TDS and $\mathrm{pH}$ were measured to control runoff quality. According to the results, 1.12 million cubic meters (MCM) per year of runoff can be injected to the aquifer via 9 designed injection wells. This amount is equivalent to the annual loss of the aquifer (about 20 centimeters per year) that can ensure the stability of the aquifer in the injection area.
Keywords: Groundwater; injection well; MODFLOW; rainfall; SWMM model.

\section{Introduction}

Groundwater resource is a sure and healthy source of water in the world, especially in the arid and semi-arid area (Chilton, 1999, Ellis, 1999, Lerner, 1996). In the recent years, the excessive utilization of groundwater resources has created major problems such as depletion of aquifers(Ehsan, 2013; Foster et al., 1998). Various procedures such as rainwater harvesting (RWH), artificial groundwater recharge, and use of alternative water were suggested to decrease groundwater discharge (Singh et al., 2017). Urbanization should provide a wide impermeable surface with a high potential of runoff production. Rainfall collection systems could avoid water demand pressures associated with climatic, environmental and societal changes (Campisano et al., 2017). A few suitable areas exist in the urban area for inland storage, while injection of the runoff to the aquifers have a high potential for groundwater recharge that not only enhance groundwater resource but also should decrease evapotranspiration (Technical reports from the Department of Water Sciences of Australia, 2011). Urban areas can acts as a water harvesting system that produce a great amounts of runoff (Dietz and Clausen, 2008, Schoonover et al., 2006, Wang et al., 2005) that should use for artificial recharge of the aquifers. Implementation of such management method in urban area were suggested by numerous researchers (Ehsan, 2013, Ferguson, 2015, Kulkarni, 2015, Narula, 2014, Vázquez-Suñé et al., 2010, Yergeau, 2010, Singh et al., 2017).

Various direct and indirect artificial recharge methods are suggested to transfer surface runoff into the aquifer (Todd and Mays, 2005a, Water, 2000, Todd and Mays, 2005b). In the direct methods, runoff straightly transferred to the aquifer using a bore hole, and consequently, minimum runoff losses will occur (Council, 1994; Kattan et al., 2010; Ehsan, 2013; Mankad et al., 2015). The results of these 
study indicate that groundwater recharge via injection wells has an effective role on improving aquifer condition.

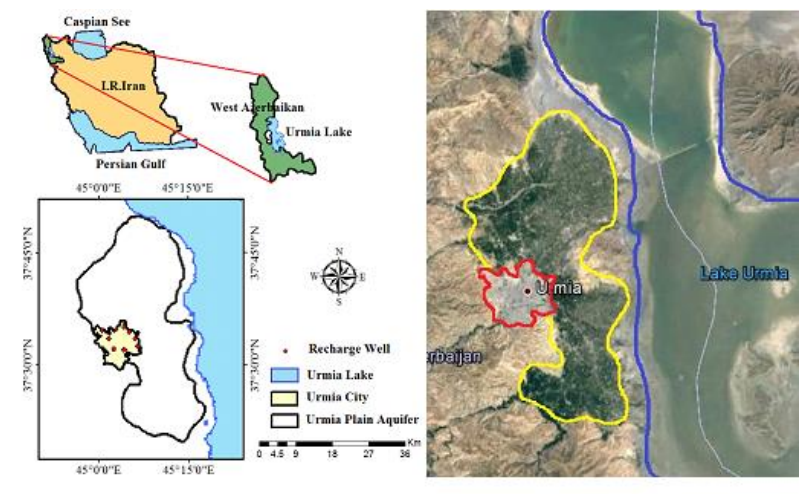

Figure 1. Location of Urmia plain in West Azerbaijan, Iran.

Direct injection of runoff to aquifer was reported by several researchers (Ferguson.,2015; Narula, 2014; Kulkarni, 2015; Eshtawi et al., 2016). To estimate the impact of surface runoff injection on groundwater level, a coupled surface water and groundwater model is needed. MODFLOW model widely used to simulate the impact of runoff injection process on the groundwater condition and the ability of MODFLOW model in the simulation of groundwater flow was confirmed (Al-Hassoun and Mohammad, 2011, Wang et al., 2008, El Yaouti et al., 2008, Ali et al., 2012, Cho et al., 2009), but detailed analysis of overland flows via MODFLOW are not possible. SWMM was extensively used in urban areas to provide detailed analysis of overland flows in the urban area. The main aims of this study is: 1) to simulate the impact of urban runoff injection on groundwater level using a coupled SWMM - MOFLOW Model, 2) to investigate the quality of the urban runoff for injecting to the aquifer and 3) to investigate the feasibility and effeteness of the artificial recharge via injection wells in a semi-arid area. Based on the intended goals, the following hypotheses were raised in this study: 1) Runoff injection increases the level and quality of groundwater, 2) Urban runoff injection is a suitable and effective method for groundwater recharge in the arid and semi-arid regions.

\section{Material and methods}

\subsection{Study area}

\subsubsection{Urmia plain aquifer}

The studied urban area named Urmia city (37응 $32^{\prime} \mathrm{N}$ and 450 02' E) located at the West of Azerbaijan providence, the west part of the Urmia Lake in the North-West of Iran (Figure 1). In this area the quality and quantity of the groundwater was decreased in the recent decade due to the groundwater over extraction and decrease of the lake water input (Ghalibaf and Moussavi, 2014).

The studied area formed of well grained sand with hydraulic conductivity equal to15.19 m.day ${ }^{-1}$ and silty- sand with hydraulic conductivity equal to $0.63 \mathrm{~m}^{-d_{a}{ }^{-1} \text { that is }}$ suitable for water harvesting operation (Todd and Mays, 2005a). The average thickness of the saturated zone in the study area is about $130 \mathrm{~m}$.
The average annual rainfall of the region is $375 \mathrm{~mm}$. Most of the rainfalls turn into runoff due to the large amounts of the impermeable area (more that $80 \%$ of the urban area is impermeable). The average annual temperature of the region is $8.9^{\circ} \mathrm{C}$.

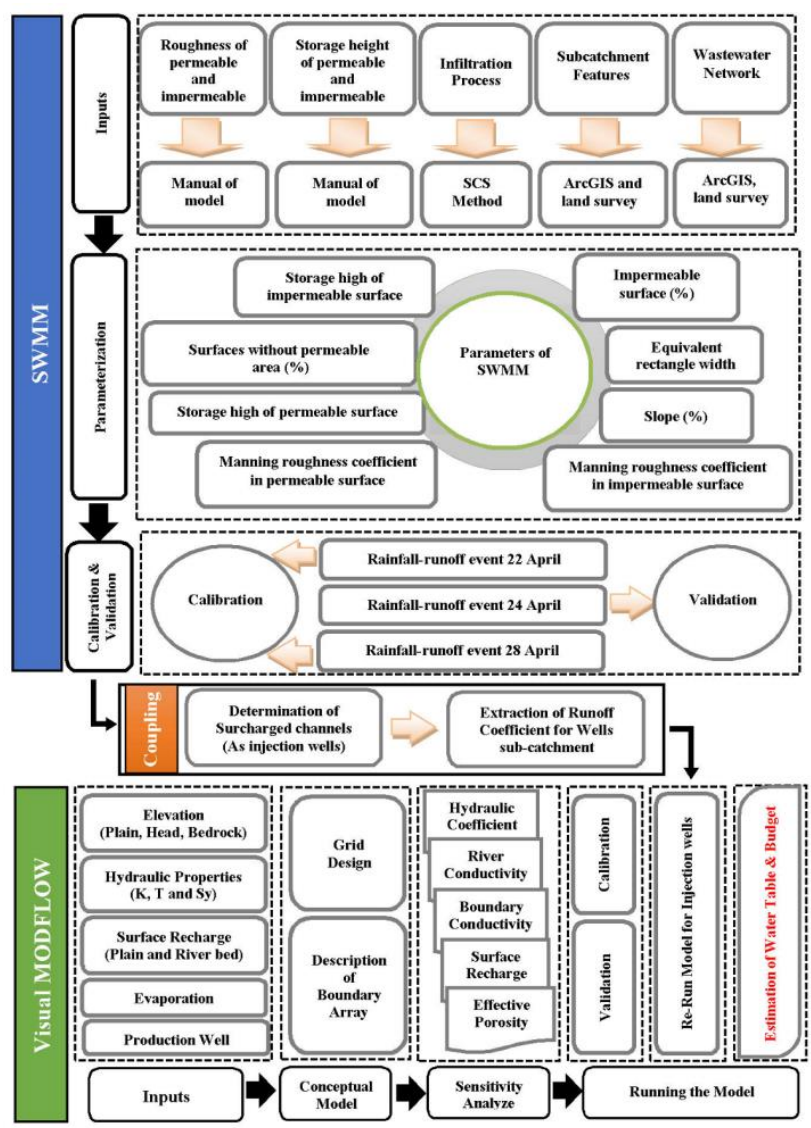

Figure 2. Flowchart of the main steps of the study methods

\subsubsection{Data Collection.}

The area of the Urmia aquifer is about $2166 \mathrm{~km}^{2}$, consist two main sections, (1) alluvial aquifer and (2) mountainous aquifer.

Alluvial aquifer with an area of $930.9 \mathrm{~km}^{2}$ consist of Quaternary alluvium and the mountainous part with an area of $293.39 \mathrm{~km}^{2}$ is made up of stony hard formations including sandstone and conglomerate (coarse-grained sedimentary rock) with a small amount of marl and shale. The depth of the aquifer varies from 64 meters at the mountainous areas to 4 meters in the vicinity of the Urmia Lake with an average aquifer depth of $11 \mathrm{~m}$ in the Urmia city. The average depth of the bedrock is about 170 meters (Water budget Report of Urmia Plain, 2014).

Groundwater is the most important water resources of the area that discharged by about 18000 extraction wells. The decline of the groundwater table by 2.50 meters over the past 12 years should explain as the results of the over extraction (Regional Water Organization of Urmia). Figure 1 shows the geographic range of the study area and the distribution of the recharge wells.

\subsection{Methodology}

In this study, SWMM and MOFLOW models were used to estimate the impact of surface runoff injection on the 
groundwater level via injection wells. Figure 2 summarize the main steps of the study methods.

\subsubsection{SWMM model}

Urban sub-Catchment features (elevation, slope, area and wide) were taken out in ArcGIS 10.3. Figure 3a shows the Digital Elevation Map (DEM) of Urmia city. Geoeye satellite images were used for preparing land use map (Figure $3 \mathrm{~b}$ ). Imperviousness and Curve Number (CN) maps were produced from land use map and land survey proceedings. Junctions and conduits location (Latitude \& Longitude), height, slope, roughness and form information were measured by land surveying.
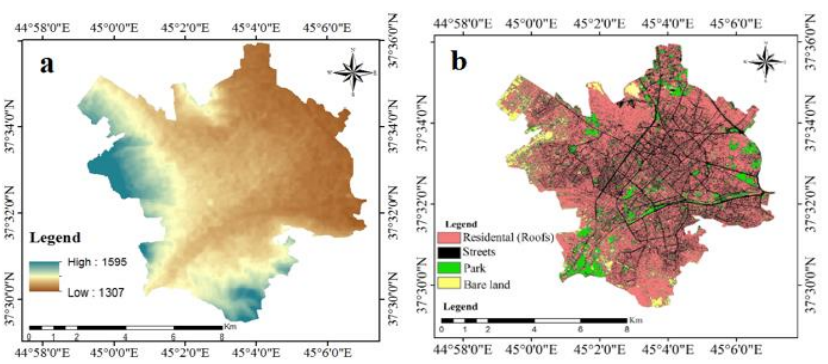

Figure 3. a: Digital Elevation Model, b: Landuse of Urmia city.

Based on flow direction, location of junctions and land use map of the study area, the urban area were divided to 22 Sub-catchments (Figure 4).

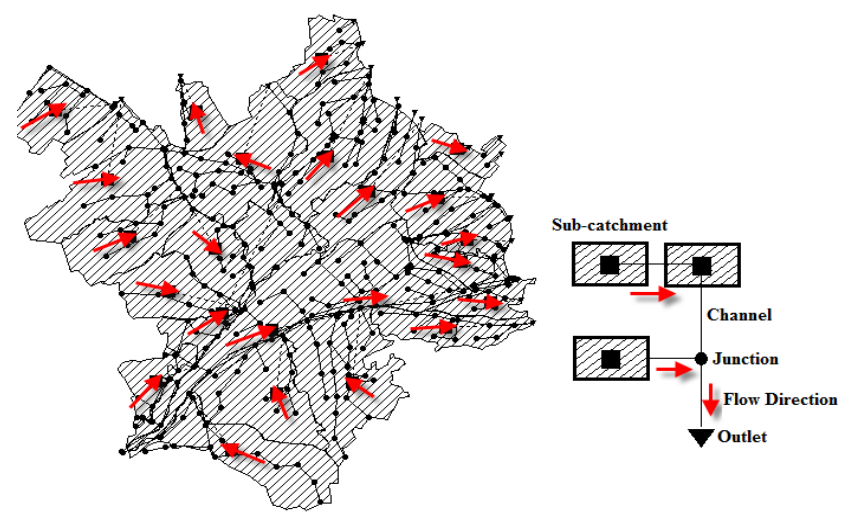

Figure 4. Sub-catchments of Urmia City designed in SWMM model.
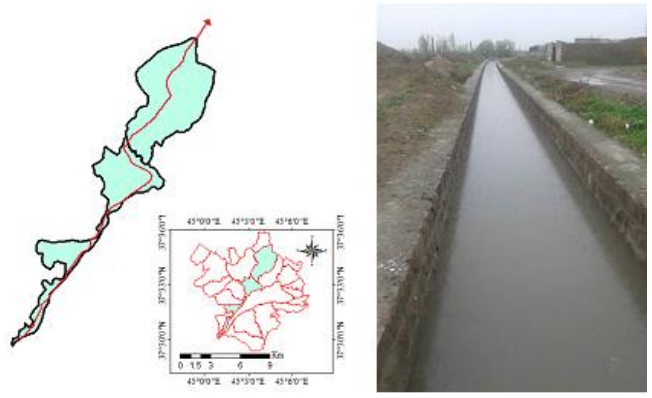

Figure 5. Outlet of the sub-catchment allocated to rainfall-runoff processes measurement.

For model calibration and validation, three rainfall- runoff events were measured for sub-catchment S11 (Figure 5). This sub-catchment has a specified output, a significant concentration time and a good representation of the physical and hydrological features of the whole basin. These rainfall events (22, 24 and 28 April 2016) were measured and used for model calibration and validation. Daily rainfall data (1981- 2015) were obtained from Urmia synoptic station to provide IDF curves (Figure 6). These curves were used to calculation of harvestable water in different return periods.
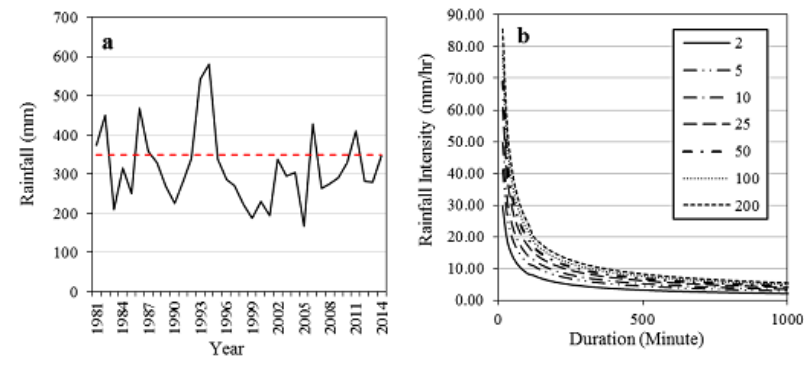

Figure 6. a: Annual rainfall of Urmia synoptic station (Red line shows the average depth of rainfall events during 35 years), b: IDF curves.

\subsubsection{Urban runoff simulation}

Rainfall-Runoff process was modeled via EPA SWMM (Storm Water Management Model). Hydrological subcatchments were delineated based on the flow direction and location of channels and junctions.

In the SWMM model, infiltration rate is processed via curve number (CN) method. For each sub-catchment, land use maps were provided for year 2011, using Geoeye images with 2 meters resolution in ENVI 5.1 and ArcGIS 10.3. The weighted $\mathrm{CN}$ is computed for each sub-catchment using equation (1):

$$
\text { Weighted } C N=\frac{\sum_{1}^{n} C N_{i} A_{i}}{\sum_{1}^{n} A_{i}}
$$

IDF curves (Intensity-Duration-Frequency) were used for estimation of runoff values for rainfall with different return periods of 2, 5 and 10 years. IDF curves were prepared using equation 2 and 3 for rainfall duration less than 2 hours and more than two hours respectively (Hessari, 1997). Time of concentration for sub-catchments were calculated via TR-55 model (NRCS, 2009) in MATLAB.

$$
\begin{aligned}
P_{T}^{t} & =[0.4548+0.2387 \operatorname{Ln}(T-0.19)] \\
& \times\left[-0.7685+0.8474 t^{0.1805}\right] \times P_{10}^{60} \\
P_{T}^{t} & =[0.5806+0.1888 \operatorname{Ln}(T-0.19)] \\
& \times\left[0.3594+0.09344 t^{0.4757}\right] \times P_{10}^{60}
\end{aligned}
$$

Where:

$P_{T}^{t}$ is the rainfall depth with a return period of T year and a duration of $t$ minutes and $P_{10}^{60}$ is the rainfall depth with the return period of 10 years and the duration of 60 minutes, $P_{10}^{60}$ was obtained from the equation (4).

$$
P_{10}^{60}=2.26 \times\left(P_{\operatorname{max2}}^{1.1374}\right) \times\left(P_{\text {year }}^{-0.3072}\right)
$$


Manning roughness coefficient was obtained from model manuals ASCE. (1992) and McCuen et al. (1996). Depth of depression storage on pervious and impervious area were obtained from the suggested values by ASCE (1992). Physiographic features of sub-catchments including slope, elevation and flow direction as well as area and perimeter were calculated using 30- meter Digital Elevation Model and city boundary mask in ArcGIS.

\subsubsection{Calibration and validation of SWMM}

For model calibration and validation, three rainfall-runoff events were measured in 22, 24 and 28 April 2016.Two events ( 22 and 24 April) were used for model calibration and the third event (28 April) was applied for model validation.

In order to estimate the volume of rechargeable water, the effective daily rainfall events (the events with more than 1 $\mathrm{mm}$ depth), the effective area of each well and the runoff coefficient (estimated by SWMM model) were considered. Surcharged junctions in urban drainage system were recognized by calibrated SWMM to determine the proper sites.

\subsubsection{MODFLOW model}

Aster 30 meters DEM layer was used for preparing plain elevation (Figure 7a). Water table of the Urmia plain was interpolated and mapped based on the information of 53 piezometric wells (Figure 7b). Information of the complete wells were used for calculating the depth of the bedrock in ArcGIS (Figure 7c).

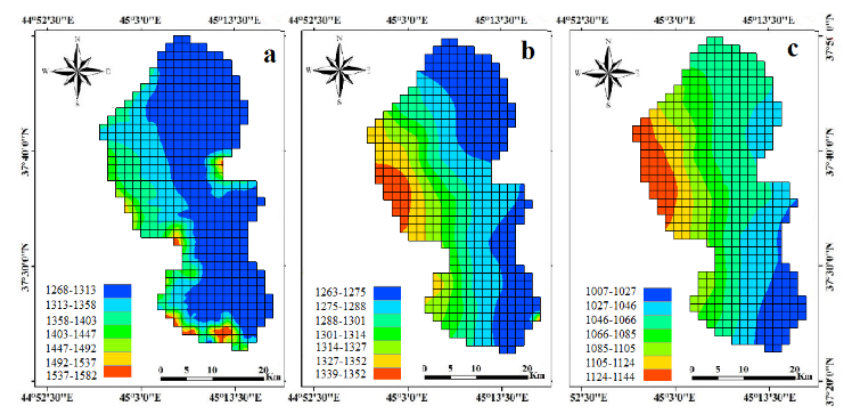

Figure 7. a: Elevation map, b: Depth of Aquifer and c: Bedrock, Urmia plain.

To validate the hydraulic head simulated by MODFLOW, 53 piezometers wells were used (Figure 8a). Daily groundwater extraction rate of the aquifer was calculated considering 18000 extraction wells in the studied plain (Figure $8 \mathrm{~b}$ ). There are four rivers in the studied plain (Figure 8c). To estimate streambeds hydraulic conductivity, a primary conductivity of $50 \mathrm{~m} /$ day was allocated and then, PEST method was used for hydraulic conductivity calibration in MODFLOW. PEST it is an automated parameter estimation tool, which provides minimum residuals in the model. Based on transmissivity of the piezometric wells and the aquifer thickness, hydraulic conductivity layer was provided (Figure 8d). Groundwater evaporation was estimated for the area where groundwater depth was more than five meter (Figure 8e). The surface infiltration (natural recharge from surface of the plain) and recharge through the rivers were mapped in ArcGIS (Figure 8f).

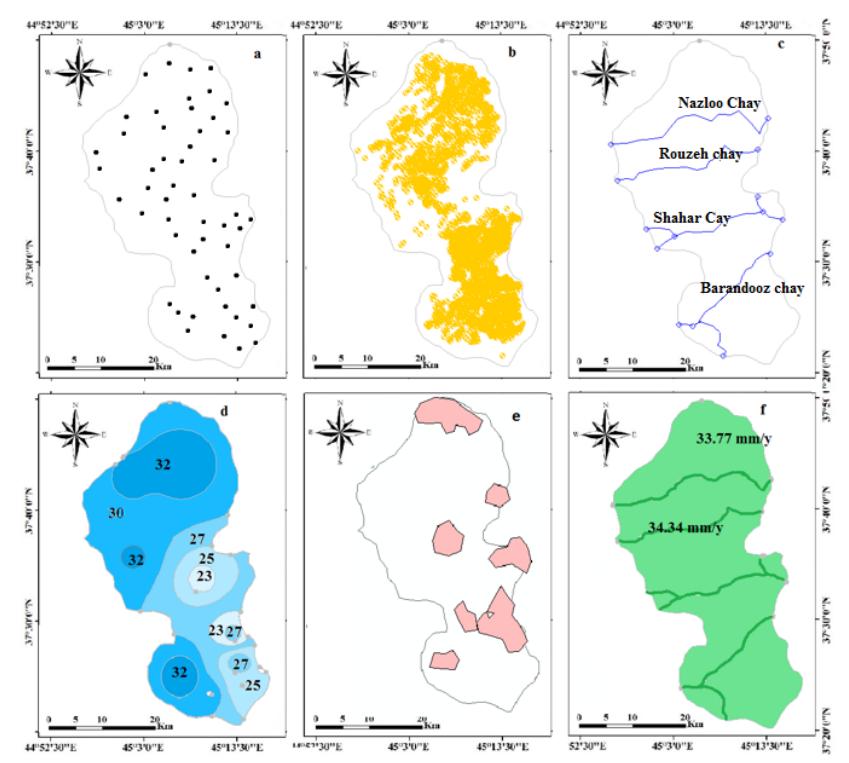

Figure 8. a: Piezometer wells, b: Extraction Wells, c: Rivers, d: Hydraulic conductivity, e: Evaporation polygons and f: Surface recharge, Urmia plain.

\subsubsection{Groundwater simulation}

MODFLOW was used to simulate the groundwater flow. The aquifer environment was divided to 903 cells (43 vertical cells and 21 horizontal cells with an area of $1000 \mathrm{~m}^{2}$ for each cell) with uniform hydrogeological properties.

Two types of active and passive cells are used to describe the boundary arrays in the MODFLOW model. For passive cells, the hydraulic head is not calculated.

Surface topography and depth of bedrock, hydraulic conductivity, transmission coefficient and porosity as the hydrostatics variable and Recharge rate, discharge, hydraulic link of the rivers, evaporation, drainage and depth of aquifer as hydrodynamic characteristics of aquifers were prepared as the inputs of the model.

MODFLOW model was calibrated for the steady condition using PEST method (The month November that storage variation of the aquifer is approximately equal to zero).

To perform an accurate calibration, sensitivity analysis was done via trial and error method. The calibrated model was applied for 60 monthly period time (2011 to 2015). NashSutcliffe coefficients (NS), average of MAE and RMSE error criteria were used to investigate the accuracy of the model.

In order to investigate the effect of artificial recharge on the study aquifer, the designed model was applied for the assumed recharge wells.

\section{Results and discussion}

\subsection{Rainfall-runoff simulation}

According to results, SWMM model has a suitable accuracy for simulation of the rainfall-runoff events in the study area (Ns=0.88 and 0.94; MAE=1.33and 1.04; RMSE=1.36 and 1.21 for calibration and validation processes respectively 
(Table 1). Figure 9 shows observed and simulated hydrographs of 3 specific rainfall events. Results show that peak runoff was occurred about 2 hours after peak of rainfall (equal to concentration time).
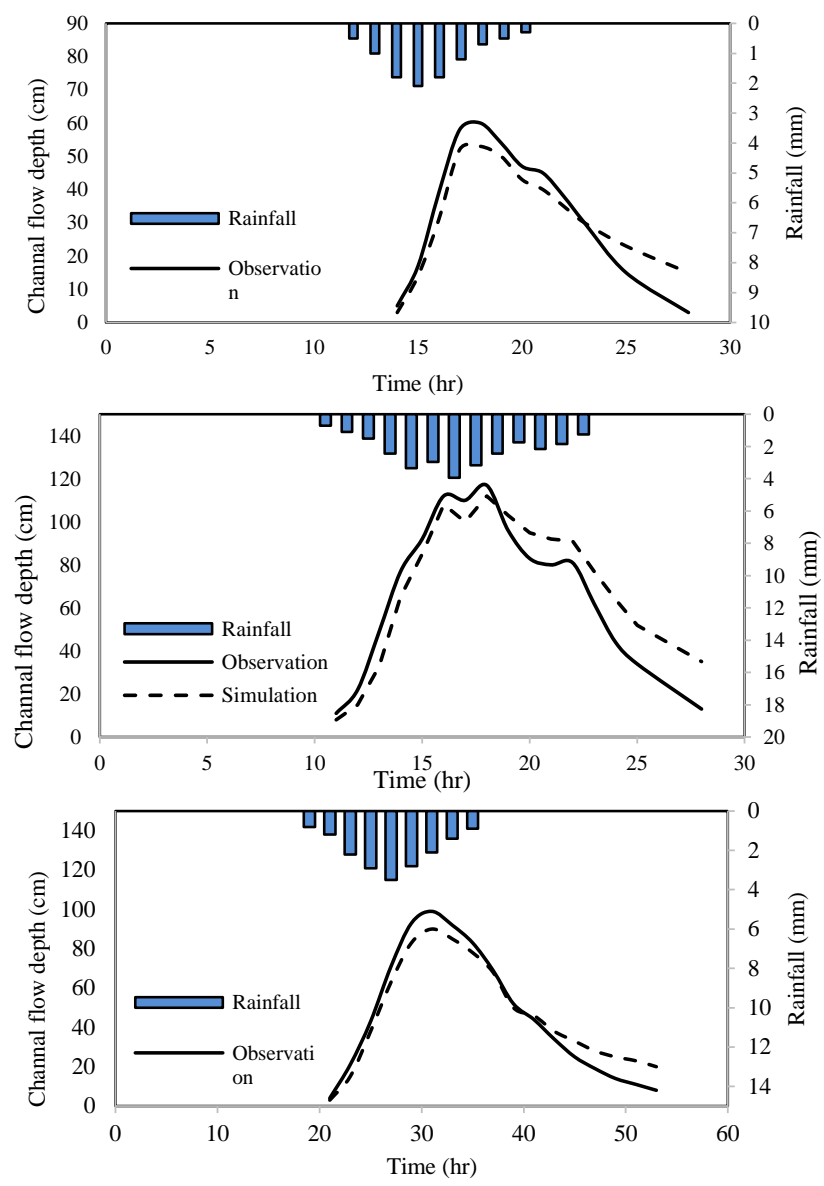

Figure 9. Rainfall-runoff process in 22, 24 and 28 April 2016 respectively.

After model validation, based on the rainfall with a return period of 10 years estimated via IDF curves, surcharged channels, junctions and runoff coefficient were investigated. In order to provide IDF curves, 30 years daily rainfall obtained from Urmia synoptic station was used (1985-2014). Rainfall hyetograph was established based on the alternative blocks method (SCS Type II). Several rainfall events were analyzed to identify suitable alternative blocks patterns.

Surcharged junctions (Figure 10) were recognized using SWMM model and considered as the suitable site for injection wells. For each injection wells, the volume of the harvestable water was estimated based on the runoff coefficient, sub-catchment characteristics (area, slope and $\mathrm{CN}$ ), and rainfall events in the recent five years (20112015). Sub-catchments features are presented in Table 2.

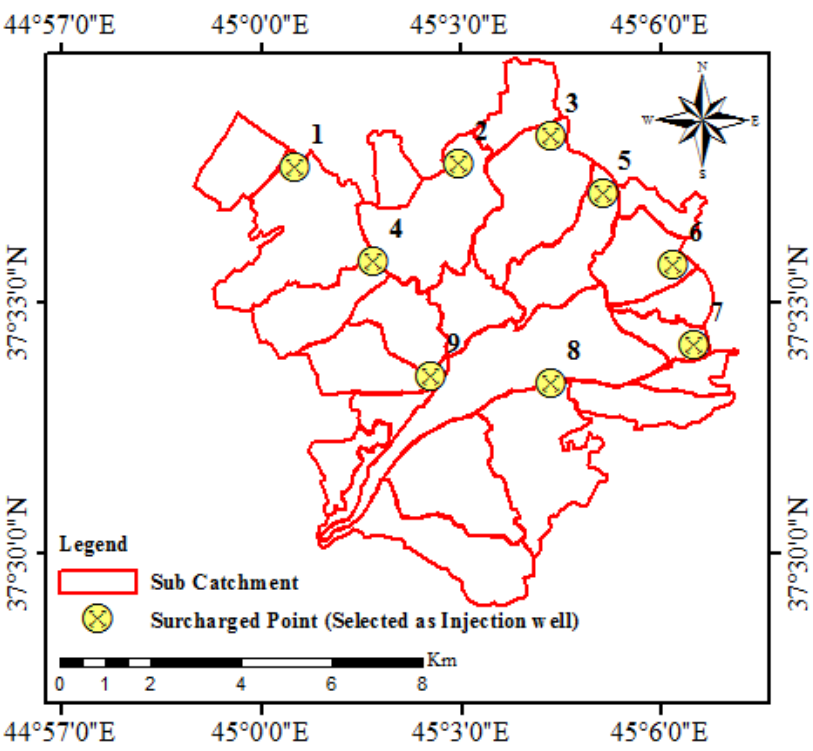

Figure 10. Surcharged junctions selected as injection well sites.

\subsection{Simulating the impact of surface runoff injection on groundwater using MODFLOW}

The impact of surface runoff injection on groundwater was simulated using MODFLOW model. At first step, the model was calibrated in the steady state condition and then, groundwater budget was simulated for the steady and transient conditions using calibrated MODFLOW model.

Results of the sensitivity analyze showed that the most sensitive parameters of the MODFLOW model were hydraulic and river conductivity, whereas the least sensitive parameters were the effective porosity and hydraulic conductivity in the aquifer boundary (Figure 11a). Therefore, the calibration of the model was carried out based on the hydraulic conductivity of the aquifer, hydraulic conductivity of the river bed, and surface recharge in a steady state.

According to results, calibrated MODFLOW model has a suitable accuracy for simulation of the groundwater in the study area $\left(R^{2}=0.98 ; M A E=1.43 ; R M S E=2.13\right.$ for (Figure 11b). Calibrated model was used for simulation of 3dimentional groundwater flow in the steady and unsteady conditions.

For the steady condition, the largest amount of water recharge to the aquifer occurs by the rivers and aquifer's boundary. Surface groundwater recharge via infiltration was about 22 percent. The largest amount of the aquifer discharge was mainly related to 18000 extraction wells and then aquifer boundary (Table 3 ). The amount of discharge by the rivers and bottom drainage was negligible.

Table 1. Rainfall- runoff events and calibration of the model results with peak flow

\begin{tabular}{cccc}
\hline Rainfall- runoff events & RMSE $\left(\mathbf{m}^{\mathbf{3}} / \mathbf{s e c}\right)$ & MAE $\left(\mathbf{m}^{\mathbf{3}} / \mathbf{s e c}\right)$ & Nash- Sutcliffe coefficient \\
\hline 22 April (Calibration) & 2.01 & 1.99 & 0.86 \\
\hline 24 April (Calibration) & 0.72 & 0.67 & 0.90 \\
\hline 28 April (Validation) & 1.21 & 1.04 & 0.94 \\
\hline
\end{tabular}


Table 2. Runoff coefficient and some feature of sub-catchments related to selected sites

\begin{tabular}{ccccc}
\hline Site No. & $\begin{array}{c}\text { Area of sub-catchment } \\
\left(\mathbf{K m}^{2}\right)\end{array}$ & Slop (\%) & Runoff coefficient \\
\hline 1 & 5.92 & 5.68 & 79.28 & 0.66 \\
\hline 2 & 5.04 & 4.74 & 75.86 & 0.64 \\
\hline 3 & 4.91 & 1.10 & 85.63 & 0.77 \\
\hline 4 & 2.42 & 4.93 & 73.50 & 0.75 \\
\hline 5 & 3.4 & 1.10 & 85.56 & 0.69 \\
\hline 6 & 2.29 & 1.48 & 82.91 & 0.72 \\
\hline 7 & 1.67 & 1.33 & 74.42 & 0.57 \\
\hline 8 & 2.19 & 3.44 & 90.84 & 0.80 \\
\hline 9 & 8.06 & 1.15 & 80.63 & 0.67 \\
\hline
\end{tabular}
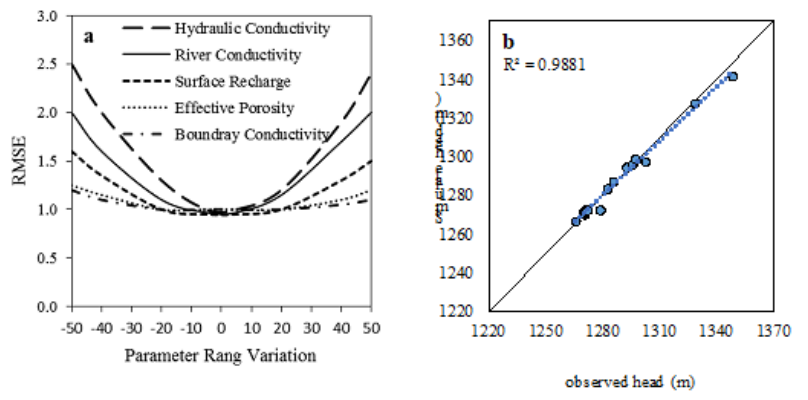

Figure 11. a: Sensitivity analyze of MODFLOW and b: scatter plot of observed and simulated data, Urmia plain.

In order to study the impact of injection on groundwater variation, the aquifer was simulated for 5 years (20112014) under two scenarios: 1) when the estimated runoff injects to the aquifer and 2) when injection and groundwater recharge are similar to the current conditions of the aquifer.

\subsubsection{Scenarios (1-1): Injection all of the harvested runoff to the borewell}

According to results, considering runoff coefficients obtained from SWMM, sub-catchments area and rainfall events, selected sub-catchments have potential for production of 8.1 million cubic meters (MCM) of runoff per year. The number of rainfall events and volume of the runoff for each season is presented in Table 4.
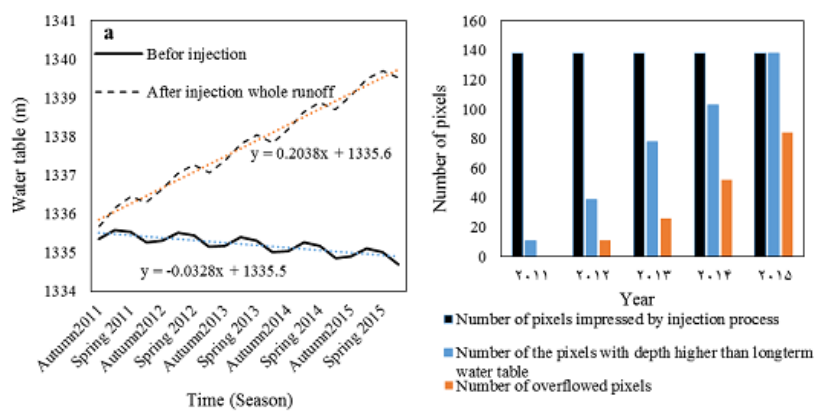

Figure 12. a: Water table of Urmia plain aquifer in the injection site (urban area) before and after injection, b: Number of pixels overflowed during the time.

Calibrated MODFLOW model was applied for modeling the artificial recharge practice on the groundwater table. For similar condition of rainfall events during 2011-2015, groundwater level of the study aquifer in urban area souled increase by $4.81 \mathrm{~m}$ during 5 years

(Figure 12a). As groundwater table in some area of the aquifer is less than $4.81 \mathrm{~m}$, groundwater level should overflow on the ground under this scenario (Figure 12b). Consequently, the amount of the injected runoff should be determined based on the hydrostatic conditions of the aquifer.
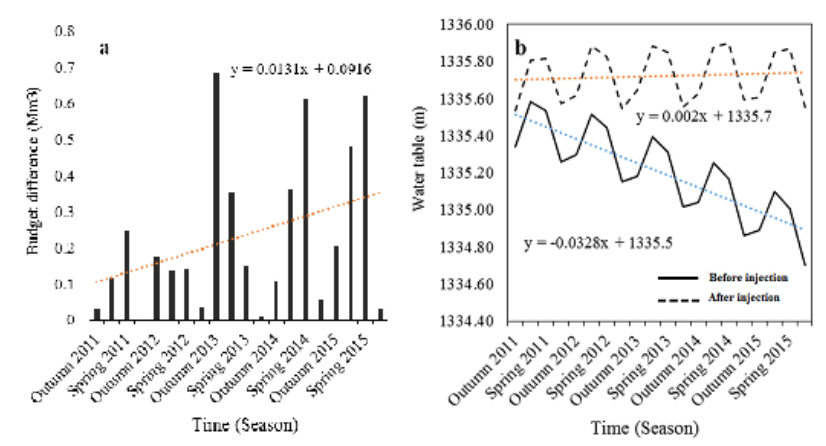

Figure 13. a: Variation of the aquifer budget, $b$ : Water table of Urmia plain aquifer in the injection site (urban area) before and after injection.

\subsubsection{Scenarios (1-2): Injection a part of the harvested runoff according to the current conditions of the aquifer.}

In order to prevent groundwater overflowing, the annual potential of aquifer for surface water injection was determined using try and error approach (Table 5). According to results, the annual capacity of the aquifer for groundwater recharge is about $1.12 \mathrm{MCM}$.

According to the results, before surface urban runoff injection, annual groundwater budget of the study aquifer was usually negative in the spring and summer seasons (Table 6). At the end of the spring and summer 2011, the aquifer water budget were- 0.005 and -0.006 before runoff injection and increased to 0.241 and -0.004 after application of the harvested runoff (Scenarios (1-2)). In the second year of the injection, a positive water budget was estimated for the study aquifer (Table 6 and Figure 13a).

According to the results, annual groundwater level declination was $20 \mathrm{~cm}$ in the current condition (Figure 13b). The injection process, not only can prevent a downward trend in the hydraulic head of studied aquifer, but also it 
can increase groundwater table and ensure the seasonal and annual stability of the aquifer.

Table. 3. Groundwater budget in the steady state (Average of November during study period)

\begin{tabular}{cccc}
\hline Source & Volume (Million $\mathbf{M}^{\mathbf{3}}$ ) & Sink & Volume (Million $\mathbf{M}^{\mathbf{3}}$ ) \\
\hline Aquifer boundary & 16.71 & Aquifer boundary & -12.06 \\
\hline River & 20.75 & River & -3.17 \\
\hline Surface & 10.56 & Drainage & -2.62 \\
\hline & & Production Well & -30.17 \\
\hline Total rate & 48.027 & & -48.033 \\
\hline Source-Sink & & -0.006 &
\end{tabular}

Table 4. Harvestable surface runoff from urban sub-catchments

\begin{tabular}{|c|c|c|c|c|c|c|c|}
\hline Year & Season & No. & Injection Volume $\mathrm{Mm}^{3}$ & Year & Season & No. & Injection Volume $\mathrm{Mm}^{3}$ \\
\hline \multirow{4}{*}{2011} & Autumn & 18 & 2.11 & \multirow{4}{*}{2014} & Autumn & 20 & 2.13 \\
\hline & Winter & 29 & 2.05 & & Winter & 23 & 2.46 \\
\hline & Spring & 30 & 3.44 & & Spring & 32 & 2.95 \\
\hline & Summer & 4 & 0.56 & & Summer & 7 & 0.27 \\
\hline \multirow{4}{*}{2012} & Autumn & 18 & 2.70 & \multirow{4}{*}{2015} & Autumn & 22 & 2.51 \\
\hline & Winter & 27 & 2.65 & & Winter & 19 & 2.07 \\
\hline & Spring & 37 & 2.45 & & Spring & 28 & 2.99 \\
\hline & Summer & 5 & 0.67 & & Summer & 7 & 0.14 \\
\hline \multirow{4}{*}{2013} & Autumn & 26 & 2.23 & & & & \\
\hline & Winter & 21 & 2.02 & & & & \\
\hline & Spring & 23 & 3.01 & & & & \\
\hline & Summer & 8 & 0.62 & & & & \\
\hline
\end{tabular}

Table 5. Injectable runoff considering current condition of aquifer

\begin{tabular}{|c|c|c|c|c|c|}
\hline Year & Season & Injection Volume $\mathrm{Mm}^{3}$ & Year & Season & Injection Volume $\mathrm{Mm}^{3}$ \\
\hline \multirow{4}{*}{2011} & Autumn & 0.37 & \multirow{4}{*}{2014} & Autumn & 0.29 \\
\hline & Winter & 0.36 & & Winter & 0.43 \\
\hline & Spring & 0.61 & & Spring & 0.48 \\
\hline & Summer & 0.10 & & Summer & 0.03 \\
\hline \multirow{4}{*}{2012} & Autumn & 0.31 & \multirow{4}{*}{2015} & & \\
\hline & Winter & 0.30 & & Winter & 0.31 \\
\hline & Spring & 0.45 & & Spring & 0.16 \\
\hline & Summer & 0.12 & & Summer & 0.02 \\
\hline \multirow{4}{*}{2013} & Autumn & 0.39 & & & \\
\hline & Winter & 0.25 & & & \\
\hline & Spring & 0.37 & & & \\
\hline & Summer & 0.11 & & & \\
\hline
\end{tabular}

Table 6. Effect of runoff injection process on aquifer budget

\begin{tabular}{|c|c|c|c|c|c|c|c|}
\hline Year & Season & $\begin{array}{c}\text { Before } \\
\text { Injection MCM }\end{array}$ & $\begin{array}{l}\text { After Injection } \\
\text { MCM }\end{array}$ & Year & Season & $\begin{array}{c}\text { Before } \\
\text { Injection MCM }\end{array}$ & $\begin{array}{c}\text { After Injection } \\
\text { MCM }\end{array}$ \\
\hline \multirow{4}{*}{2011} & Autumn & 0.069 & 0.102 & \multirow{4}{*}{2014} & Autumn & 0.054 & 0.164 \\
\hline & Winter & 0.067 & 0.184 & & Winter & 0.259 & 0.420 \\
\hline & Spring & -0.005 & 0.240 & & Spring & -0.023 & 0.589 \\
\hline & Summer & -0.006 & -0.004 & & Summer & -0.026 & 0.033 \\
\hline \multirow{4}{*}{2012} & Autumn & 0.070 & 0.246 & \multirow{4}{*}{2015} & Autumn & 0.053 & 0.026 \\
\hline & Winter & 0.069 & 0.208 & & Winter & 0.054 & 0.534 \\
\hline & Spring & 0.030 & 0.145 & & Spring & -0.012 & 0.611 \\
\hline & Summer & -0.017 & 0.018 & & Summer & -0.017 & 0.015 \\
\hline \multirow{4}{*}{2013} & Autumn & 0.058 & 0.745 & & & & \\
\hline & Winter & 0.063 & 0.419 & & & & \\
\hline & Spring & -0.023 & 0.129 & & & & \\
\hline & Summer & -0.028 & 0.018 & & & & \\
\hline
\end{tabular}


where runoff pollution exceeds the standards defined for groundwater quality, several management practices, including treatment strategies and pollution prevention strategies should be applied to mitigate stormwater pollution.

In this study, to evaluate the runoff quality, heavy metals $\left(\mathrm{Fe}^{2+}, \mathrm{Pb}^{2+}, \mathrm{Zn}^{2+}, \mathrm{Mn}^{2+}\right.$ and $\left.\mathrm{Cu}^{2+}\right), \mathrm{TDS}, \mathrm{BOD}$ and $\mathrm{pH}$ were measured for base flow and channel discharge at the depth of $0.5 \mathrm{~m}$. The results were compared with the global groundwater quality standard (Groundwater Quality Standards report, 2014).

According to the results, the amount of all measured elements except the $\mathrm{Fe}^{2+}$ is acceptable compared to standard value for measured runoff. Comparison of the amount of these elements in the runoff before and after rainfall events shows that the quality of runoff has improved significantly (Figure 14). The amount of $\mathrm{Zn}^{2+}, \mathrm{Pb}^{2+}$ and $\mathrm{Cu}^{2+}$ in both before and after rainfall is significantly lower than the global groundwater standard. The amount of $\mathrm{Zn}^{2+}$ and $\mathrm{pH}$ before rainfall events is higher than the standard values, while after precipitation, its concentration becomes lower than standard value. In this study, due to some limitation, only three rainfall runoff qualities were measured in spring season, consequently, we can conclude that runoff quality was suitable after rainfall seasons. More measurements in the other seasons are needed to ensure about the quality of the injectable runoff.
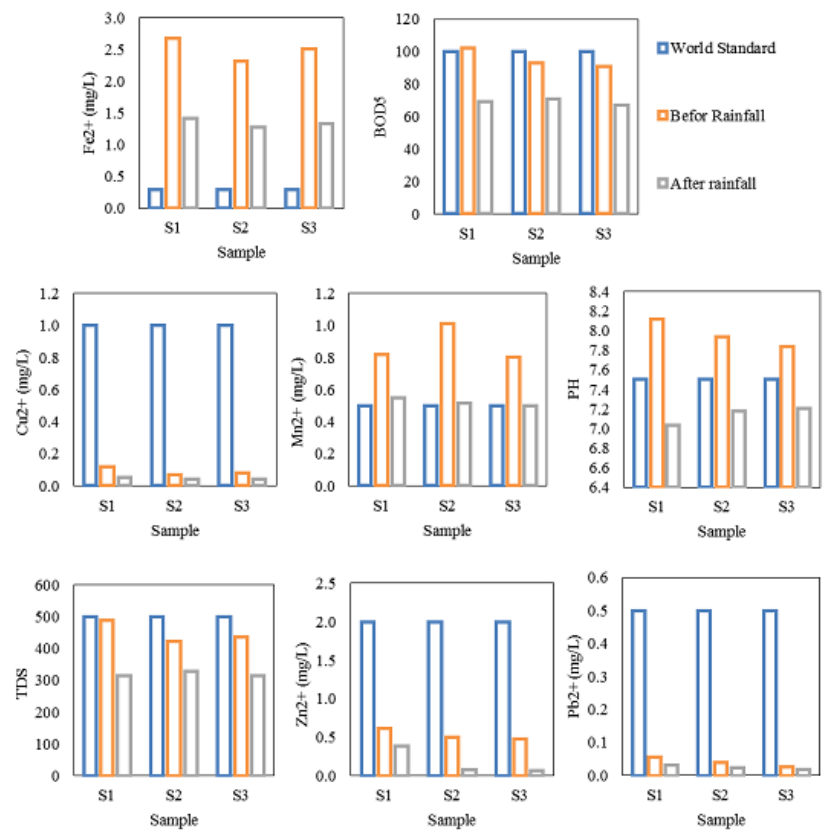

Figure 14. Runoff quality before and after rainfall events in April 2016.

\section{Conclusion}

In order to evaluate the effect of urban runoff injection, the amount of monthly injectable runoff was estimated via SWMM model. The critical sub-catchments prone to flooding, where the junction points should potentially surcharge; were selected as suitable area for injection well. The amounts of surface runoff in these junctions were also simulated. In this research, the quality analyzes of surface runoff were also carried out after several rainfall events in the spring. The surface runoff should have an acceptable quality to be injected into the aquifer except for the primary rainfall events occurring at the beginning of fall season. We recommended more measurements in the other seasons to assure the quality if the injectable runoff. However some researchers such as Ferguson (2015), believed that widespread environmental damage is unlikely in runoff and wastewater injection (Li et al., 2012, Nabizadeh et al., 2005, Wang et al., 2017). Mankad et al. (2015) Presented various reasons for acceptance of aquifer recharge using stormwater.

Simulation of surface runoff injection showed that water table in the post-injection phase increased significantly. Such results were confirmed by Kulkarni (2015) and Ferguson (2015). In this study, groundwater table was improved significantly around the injection region, but injection effects were decreased with increasing distance to the injection wells. Transferring and injection of runoff in the other parts of the aquifer and using other runoff harvesting techniques can be an effective way to control floods and water supply in such areas.

Climatic factors such as the number of rainfall events and precipitation depth as well as distribution of rainfall events in different season could impress the rechargeable amount of runoff. Hydraulic condition of the saturated zone has also an important role on the potential of the water absorption by aquifer.

\section{Acknowledgements}

This work was funded through the University of Kashan in Iran as a PhD thesis and by the Iranian National Science Foundation (Grant No: 95850079). The authors appreciate the University of Kashan and the Iranian National Science Foundation for their generous support.

\section{References}

Al-Hassoun, S. A. and Mohammad, T. A. (2011). Prediction of Water Table in an Alluvial Aquifer Using Modflow.

Ali, R., Mcfarlane, D., Varma, S., Dawes, W., Emelyanova, I., Hodgson, G. and Charles, S. (2012). Potential climate change impacts on groundwater resources of south-western Australia. Journal of Hydrology, 475, 456-472.

ASCE. (1992). Design and construction of urban stormwater management systems.

Campisano, A., Butler, D., Ward, S., Burns, M. J., Friedler, E., Debusk, K., Fisher-Jeffes, L. N., Ghisi, E., Rahman, A. and Furumai, H. (2017). Urban rainwater harvesting systems: Research, implementation and future perspectives. Water research, 115, 195-209.

Chilton, J. (1999). Groundwater in the urban environment, AA Balkema.

Cho, J., Barone, V. and Mostaghimi, S. (2009). Simulation of land use impacts on groundwater levels and streamflow in a Virginia watershed. Agricultural water management, 96, $1-11$.

Council, N. R. (1994). Ground water recharge using waters of impaired quality, National Academies Press. 
Dietz, M. E. and Clausen, J. C. (2008). Stormwater runoff and export changes with development in a traditional and low impact subdivision. Journal of Environmental Management, 87, 560-566.

Ehsan, S. (2013). Utilization of Storm Runoff for Groundwater Recharge in Urban Areas-A Case Study of Gujranwala City in Pakistan. Journal of River Engineering, 1, 18-28.

El Yaouti, F., El Mandour, A., Khattach, D. and Kaufmann, O. (2008). Modelling groundwater flow and advective contaminant transport in the Bou-Areg unconfined aquifer (NE Morocco). Journal of Hydro-environment Research, 2, 192-209.

Ellis, J. B. (1999). Impacts of Urban Growth on Surface Water and Groundwater Quality: Proceedings of an International Symposium Held During IUGG 99, the XXII General Assembly of the International Union of Geodesy and Geophysics, at Birmingham, UK 18-30 July 1999, IAHS Press.

Eshtawi, T., Evers, M., Tischbein, B. and Diekkruger, B. (2016). Integrated hydrologic modeling as a key for sustainable urban water resources planning. Water research, 101, 411-428.

Ferguson, G. (2015). Deep injection of waste water in the western Canada sedimentary basin. Groundwater, 53, 187-194.

Foster, S. S., Lawrence, A. and Morris, B. (1998). Groundwater in urban development: assessing management needs and formulating policy strategies, World Bank Publications.

Ghalibaf, M. B. and Moussavi, Z. (2014). Development and Environment in Urmia Lake of Iran. European Journal of Sustainable Development, 3, 219.

Kattan, Z., Kadkoy, N., Nasser, S., Safadi, M. and HAMED, A. (2010). Isotopes and geochemistry in a managed aquifer recharge scheme: a case study of fresh water injection at the Damascus University Campus, Syria. Hydrological processes, 24, 1791-1805.

Kulkarni, N. (2015). Numerical simulation of groundwater recharge from an injection well. International Journal of Water Resources and Environmental Engineering, 7, 75-83.

Lerner, D. N. (1996). Guest editor's preface: theme issue on urban groundwater. Hydrogeology Journal, 4, 4-5.

Li, W., Shen, Z., Tian, T., Liu, R. and Qiu, J. (2012). Temporal variation of heavy metal pollution in urban stormwater runoff. Frontiers of Environmental Science and Engineering, 6, 692-700.

Mankad, A., Walton, A. and Alexander, K. (2015). Key dimensions of public acceptance for managed aquifer recharge of urban stormwater. Journal of Cleaner Production, 89, 214-223.

Mccuen, R., Johnson, P. and Ragan, R. (1996). Hydrology, Hydraulic Design Series No. 2. FHWA-SA-96-067, Federal Highway Administration, US Department of Transportation, Washington, DC.

Nabizadeh, R., Mahvi, A., Mardani, G. and Yunesian, M. (2005). Study of heavy metals in urban runoff. International Journal of Environmental Science and Technology, 1, 325-333.

Narula, A. (2014). Feasibility of recharge shafts/injection wells for groundwater recharge in Patan district, Gujarat, India. International Journal of Advanced Research in Engineering and Applied Sciences, 3, 10-19.

NRCS. (2009). Small Watershed Hydrology Win TR-55 User Guide, Issued January.

Schoonover, J. E., Lockaby, B. G. and Helms, B. S. (2006). Impacts of land cover on stream hydrology in the west Georgia piedmont, USA. Journal of Environmental Quality, 35, 2123-2131.

Singh, L. K., Jha, M. K. and Chowdary, V. (2017). Multi-criteria analysis and GIS modeling for identifying prospective water harvesting and artificial recharge sites for sustainable water supply. Journal of Cleaner Production, 142, 1436-1456.

Todd, D. K. and Mays, L. W. (2005a. Groundwater hydrology edition, Wiley, New Jersey.

Todd, K. D. and Mays, W. L. (2005b. Groundwater Hydrology, John Wiley and Sons.

Vázquez-Suñe, E., Carrera, J., Tubau, I., Sánchez-Vila, X. and Soler, A. (2010). An approach to identify urban groundwater recharge. Hydrology and Earth System Sciences, 14, 2085-2097.

Wang, J., Zhao, Y., Yang, L., Tu, N., Xi, G. and Fang, X. (2017). Removal of Heavy Metals from Urban Stormwater Runoff Using Bioretention Media Mix. Water, 9, 854.

Wang, S., Shao, J., Song, X., Zhang, Y., Huo, Z. and Zhou, X. (2008). Application of MODFLOW and geographic information system to groundwater flow simulation in North China Plain, China. Environmental Geology, 55, 1449-1462.

Wang, Y., Choi, W. and Deal, B. M. (2005). Long-term impacts of land-use change on non-point source pollutant loads for the St. Louis metropolitan area, USA. Environmental Management, 35, 194-205.

Water, G. O. A. R. T. G. (2000). Central Ground Water Board, Ministry of Water Resources. New Dehli, India

Yergeau, S. E. (2010). Development and application of a coupled SWMM-MODFLOW model for an urban wetland. Rutgers University-Graduate School-New Brunswick. 